\title{
LANGUAGE AS SOCIAL PRACTICE: \\ DECONSTRUCTING BOUNDARIES IN INTERCULTURAL BILINGUAL EDUCATION
}

\author{
LÍNGUA COMO PRÁTICA SOCIAL: DESCONSTRUINDO \\ FRONTEIRAS NA EDUCAÇÃOO BILÍNGUE INTERCULTURAL
}

\section{Virginia Zavala*}

\begin{abstract}
Although Peru's Intercultural Bilingual Education (IBE) program has been attempting to pursue new directions, it still carries many ideologies and practices that have defined it since it started half a century ago. In this article, I discuss the way some of these ideologies and practices related to language are reproduced in a preservice teacher training program in one of the capital city's private universities, which implements a national policy of social inclusion for Quechua-speaking youth from vulnerable contexts. On the basis of diverse dichotomies (L1/L2, Spanish use/Quechua use, Spanish literacy practices/Quechua literacy practices, Quechua speaker/Spanish speaker), the program produces two types of hierarchized subjectivities: one related to the subject educated in Quechua and another related to the subject educated in Spanish, both coming from a conception of languages as discrete codes that go together with fixed ethnolinguistic groups and bounded cultural practices (GARCÍA et al., 2017). In the context of new sociocultural dynamics and bilingualisms, young students in the program subvert these divisions and begin to trace new paths for IBE and Quechua in Perú.
\end{abstract}

Keywords: Quechua; youth; intercultural bilingual education.

\section{RESUMO}

Apesar do programa de Educação Intercultural Bilíngue (EIB) do Peru estar tentando buscar novas direções, ele ainda carrega no seu bojo muitas das ideologias e práticas que o vem definindo desde que iniciou há meio século. Neste artigo, discuto o modo como algumas dessas ideologias e práticas relativas a línguas são reproduzidas em um programa de treinamento pré-serviço de professores em uma das universidades particulares da capital do país, a qual implementa uma política nacional de inclusão social para jovens falantes de quéchua oriundos de contextos vulneráveis. Tendo por base dicotomias diversas (L1/L2, uso do espanhol/uso do quéchua, práticas de letramento em espanhol/práticas de letramento em quéchua, falante de quéchua/falante de espanhol), o programa produz dois tipos de subjetividades hierarquizadas: uma relativa ao sujeito educado em quéchua e uma outra relativa ao sujeito educado em espanhol, ambas derivadas da noção de línguas como códigos discretos e vinculadas a determinados grupos etnolinguísticos e a práticas culturais bem

\footnotetext{
* Pontificia Universidad Católica del Perú, Perú. vzavala@pucp.edu.pe
} 
demarcadas (GARCÍA et al., 2017). Em um contexto de novas dinâmicas socioculturais e de novos bilinguismos, os jovens alunos do programa subvertem essas dicotomias e começam a traçar novos caminhos para a EIB e para o quéchua no Peru.

Palavras-chave: Quéchua; juventude; educação intercultural bilíngue.

\section{INTRODUCTION}

The increment of new communication technologies, the intensification of transnational flows, and the linguistic changes brought forward by globalization are now part of social life in the 21 st century. This new scenario has led to tensions and challenges for multilingualism in indigenous contexts with regard to how languages are understood (PIETIKÄINEN et al., 2016). In the face of this, a new sociolinguistics of multilingualism is being forged (MARTIN-JONES \& MARTIN, 2017): one that problematizes taken for granted categories and no longer considers that languages are bounded entities, identities are stable, and communities are homogeneous (HELLER, 2007; MAKONI \& PENNYCOOK, 2006; GARCÍA, 2009).

In this article, I will look at a preservice teacher education program in Intercultural Bilingual Education (IBE) in the city of Lima in order to address how multiple and competing language ideologies about Quechua are simultaneously at work in relation to different conceptualizations of language, language boundaries, and speakers. The program that I study will be seen as a nexus of multilingual dynamics (SCOLLON \& SCOLLON, 2004), with multiple discourses being reproduced by different kinds of social actors within a language policy process (JOHNSON, 2013).

One of my main interests when approaching this program was to look at the way that the institution deals with teaching academic writing in Spanish and Quechua in higher education. After two years of fieldwork, I found that the institution regulates specific language ideologies and practices, which involve dividing or compartmentalizing the languages, the texts, the discourse genres, and the literacy practices in relation to Quechua and Spanish. As a consequence, it also produces two types of hierarchical subjectivities: one linked to the subject educated entirely in Quechua and another to the subject educated entirely in Spanish, within a conception of languages as separate codes that are related to fixed ethnolinguistic groups and bounded cultural practices (GARCÍA et al., 2017). However, in the context of new sociocultural dynamics and bilingualisms, young students in the program subvert these divisions, open spaces for the legitimation 
of new subjectivities (VALDÉS, 2017), and begin to trace new paths for IBE and Quechua in Perú.

\section{HISTORICAL CONTEXT}

The process of castellanización, or the promotion of Spanish and the exclusion of indigenous languages together with the imposition of linguistic and cultural homogeneity has been the hegemonic practice since the instauration of the Peruvian Republic in the 19th century and for more than half of the 20th century (TRAPNELL \& ZAVALA, 2013). Although different kinds of bilingual education initiatives were developed throughout the 20th century, it was not until de 1970s that bilingual education became part of official policies and was implemented by the State. In 1974, the Quechua language was made official, although this did not have much impact in practice. For almost five decades, there has been a great deal of discrepancy around the definition and purposes of bilingual education (or intercultural bilingual education since the 1980s), which can also be found in the wide range of practices observed in primary classrooms (ZAVALA, 2014a). For instance, even though the official discourse dictates a "maintenance" model of IBE, the fact that this type of education has only been implemented in rural and primary schools for almost half a century reveals a transitional model, in which Quechua is no longer seen as useful when the children learn Spanish. Hence, in a context where the use of the Quechua language has long been associated with social and political marginalization, economic poverty, and low educational achievement, IBE has acquired a remedial and compensatory connotation with the risk of turning into a tool for social reproduction (GARCÍA, 2005; HORNBERGER, 2000; VALDIVIEZO, 2009; TRAPNELL \& ZAVALA, 2013).

Multiple social actors have been involved in the language policy process since the 1970s. Within a top-down approach, linguists from Lima, who in general were not speakers of the indigenous language, were key in the creation of the Quechua alphabet, the implementation of bilingual education programs and the publishing of dictionaries, grammar, and literature within a view of language as an objectified unity. At that time, the Quechua-speaking population was the invisible interest group (HORNBERGER, 1995) in the sense that it did not have a voice in decision-making within the language policy processes at the national level. However, the last two decades have been witnessing language revitalization processes led by Quechua-speaking people themselves, many of whom were trained by linguists in the 1970s and 1980s and are now working in key positions 
of the State and have an important influence in official discourses and policies, at least in those circumscribed to IBE. Within a fractally recursive move (IRVINE \& GAL 2000; GAL, 2018), and appropriating the discourse of dominant linguistics, these "Quechua experts" (ZAVALA, forthcoming a) construct their authority and expertise based on particular language ideologies that tend to coincide with the dominant discourse on intercultural bilingual education in Perú and bilingual education in other contexts ${ }^{1}$. They favor traditional and grammaticalized methods for language teaching, reproduce a representation of the ideal bilingual speaker as two "perfect" monolinguals in one body, and enact reductionist language theories based on monolingual and purist perspectives, which sanction linguistic transference, borrowing, and code switching. The latter coincides with many bilingual education programs around the world, which argue that languages should be kept separate when learning and teaching them (CUMMINS, 2008). However, together with these conservative language ideologies, these Quechua experts also favor strategic essentialisms that lead them to oppose Spanish and Western culture. According to this defensive positioning, Quechua should be used only to talk about "Quechua topics" or about ancestral cultural practices from high-altitude peasant communities and should not be taught by "foreigners" who do not inhabit an authentic "Andean worldview" (ZAVALA, 2014b). In general, then, IBE has been dominated by essentializing discourses of language and identity (JAFFE, 2007), which take for granted a natural and essential link between the Quechua language and the Quechua people as a bounded and fixed cultural group, situate the language in a pre-contact past as if it were maximally different from Spanish, and promote static views of culture and tradition (TRAPNELL \& ZAVALA, 2013). Since the 1970s, the target beneficiaries of IBE have only been those children from primary schools who speak Quechua as their mother tongue, live in rural areas, and are socialized through ancestral cultural practices.

However, current globalization processes, increased mobility, a wider access to higher education and an intense use of technological advances have produced a different sociolinguistic scenario in Perú. In this context, and in contrast to the above, young, urban Quechua-speaking people in certain networks are constructing their own patterns of language use and identity, which counter the fixed patterns

1. Within the field of Language Ideologies, fractal recursivity constitutes a semiotic process that involves the projection of an opposition onto some other level (IRVINE \& GAL 2000). In the case I am analyzing, intergroup relations of domination between Spanish-speaking people and Quechua speaking ones (based on elitist Spanish literacy ideologies) are projected inward onto intragroup relations among Quechua-speaking people themselves. This reproduces the opposition between the ones who "know" and the ones who "do not know" the language, but within a smaller group. 
and reified identities that are attributed to them within official discourse (ZAVALA, forthcoming $b$ ). In fact, these people are currently challenging binarisms still reproduced in IBE official discourse, such as tradition and modernity, rural and urban, first and second language, speaker and non-speaker of an indigenous language, indigenous and non-indigenous, local and global, indigenous language and Spanish, authentic and inauthentic, etc. This phenomenon can be framed within the emerging field of indigenous youth and multilingualism, which has recently discussed the role of indigenous youth as policy makers who display agency and sociolinguistic innovation towards reshaping themselves and claiming new indigenous identities (WYMAN et al., 2014; MCCARTY ET AL., 2009; HORNBERGER \& SWINEHART, 2012). In this paper, I will show that, after a couple of semesters in the program under study, the students started to align themselves with this Quechua youth. They have reacted to the language ideologies promoted in the institution and contested this sociolinguistic regime that, according to them, restricts what they would like to do through Quechua. They have been constructing their own patterns of language use and identity display, opening up ideological spaces for new Quechua indexicalities and practices.

\section{LANGUAGE AS SOCIAL PRACTICE}

In the field of language studies, there has been a turn from a modernist and positivist language perspective to a critical and post structuralist one (PENNYCOOK, 2001). Within this paradigm, we do not study language or language forms, but rather "language practices in interrelationship to the sociohistorical political and economic conditions that produce them" (GARCÍA et al., 2017, p. 5). If we follow this approach, bilingualism would no longer be understood as a cognitive system with two linguistic compartments, but as dynamic and fluid practices that people engage with in order to produce meaning and communicate in diverse contexts of their lives (CANAGARAJAH, 2013; GARCÍA, 2009; HELLER, 2007). Therefore, instead of focusing on the languages as abstract, bounded, and autonomous codes (that are code-switched or code-mixed), a social practice perspective implies approaching bilingualism or multilingualism in terms of repertoires of linguistic or communicative resources (RYMES, 2014). Canagarajah has even questioned the notion of multilingual, since it is associated with separate languages, separate cognitive compartments, and separate language groups, and it "doesn't acommodate the dynamic interactions between languages and communities envisioned by translingual" $(2013$, p. 7). 
This epistemological turn has led various scholars in sociolinguistics and applied linguistics to theorize new conceptualizations of the notion of language. As a consequence, new terms have emerged: translanguaging (GARCÍA, 2009), flexible bilingualism (BLACKLEDGE \& CREESE, 2010), polylanguaging (JØRGENSEN, KARREBAEK, MADSEN \& MØLLER, 2011), dynamic lingualism (FLORES, 2013), transidiomatic practices (JACQUEMET, 2005), and translingual (CANAGARAJAH, 2013). More important than the question of which term to adopt is the idea of moving away from a conception of language as a discrete object towards language use as something fluid, complex, and dynamic. Instead of assuming static ideologies about language and culture as discrete, autonomous, and disconnected from social practice, the social practice perspective reveals that communication crosses named languages, that speakers use diverse repertoires of semiotic resources, that a balanced bilingualism or an equal competence in both languages hardly corresponds to the heterogeneous trajectories of bilinguals (BLOMMAERT \& BACKUS, 2011), and that mixing and alternation (or translanguaging) is the norm and does not need to be justified. In sum, then, instead of assuming languages as complete and bounded entities that are distributed in society according to different contexts, I will conceptualize them as resources of social practice that speakers use in an agentive way in order to deal with what they do in the world.

In addition, sociolinguistics and applied linguistics have started to question many of the assumptions and categories that were taken for granted for decades. Therefore, from a framework of bilingualism as social practice, scholars are problematizing closed, unitary and reified notions of language, culture, and identity, and concepts such as native speaker, diglosia, language rights, mother tongue, and speech community (BLOMMAERT, 2010; HELLER, 2011; PENNYCOOK, 2010), which are difficult to operationalize in both empirical research and language teaching. In addition, the scholarship on bilingualism as social practice has rejected the associations that are frequently established between a language, on the one hand, and a culture, an identity or a specific community on the other, as if these constitute bounded entities that correspond directly and as if identity or culture were an essential aspect of language (HELLER, 2007). In many circumstances, for example, it is assumed that only people from rural areas can be native speakers of Quechua, that the indigenous language "belongs" more to these types of "authentic" speakers, that only a native speaker can teach the language or that 
Quechua can only be used to speak and write about "Quechua topics", as if these constitute natural and decontextualized connections that cannot change (ZAVALA \& BRAÑEZ, 2017).

\section{METHODOLOGY}

This paper draws from two different ethnographic fieldwork experiences, which got connected at some point. Since 2014, I have been following the trajectories of youth who are activating the use of Quechua in urban spaces through hip hop/rap or video blogging in digital platforms and displaying alternative language ideologies to those from official discourses. In addition, since 2016, I have been researching a preservice teacher education program in Intercultural Bilingual Education in Lima, in order to address the academic literacy practices that students develop in both Spanish and Quechua. For this latter investigation (part of which I analyze here), the data comes from multiple sources: classroom observations during two semesters (of two Spanish and two Quechua courses); document analysis; multiple interviews with 6 focal students from different clusters; 8 focus groups with other 50 students; constant conversations with directors of the program, and Spanish and Quechua teachers; interactions with many students in non-university contexts (such as concerts, parties, and cultural events, among others). More than a year ago, I witnessed not only that some of the young people whose trajectories I have been following in Lima and other Peruvian provinces were starting to know each other via social networks and other means, but that they were also interacting with many of the students from the program under study in events where Quechua is used and also debated. Quechua-speaking youth from the university and also from outside the university are differentiating themselves from Quechua experts from older generations and trying to insert themselves into a new paradigm of language revitalization. For instance, an activist from Cusco who dubs Disney movies to Quechua declared:

The intention is to group ourselves and create an organization, but we do not want academics, we do not want someone who is telling us that this should be written like this. I would like a group of people who speak their language and talk about their life, or politics or soccer or whatever, without questioning who does it better or worse or who knows (the language well) or who does not. 


\section{THE PROGRAM}

In 2011, the Peruvian government developed a national policy of scholarships within a discourse of social inclusion to finance higher education of youth who were raised in vulnerable contexts. Preservice teacher education in IBE constitutes one of the university degrees that is financed by this grant and that is being implemented since 2014 in three private and prestigious universities located in Lima, under the educational policies of the Ministry of Education and the official discourse of IBE2. In the official document from the National Program of Scholarships (Programa Nacional de Becas, PRONABEC, 2014), IBE is still reproduced as a type of education for rural areas and within a compensatory discourse:

PRONABEC has created a scholarship that favors young people who would like to be bilingual teachers today in their own communities. In this document we present the problem of rural education as a challenge that PRONABEC assumes in the presence of Peruvian linguistic diversity (2014, p. 14, emphasis added).

Although the document also states that IBE seeks to "democratize society and close the gaps of social inequality" (2014, p. 18), this excerpt presuposses a series of ideological representations that reproduce the historical discourse of IBE. It establishes that, once they graduate, students from the program will have to teach in rural communities, that all of the students were born and raised in these peasant communities, or at least that they belong to them ("their own communities"), that rural education is a problem, that linguistic diversity can only be found in rural areas, and that this diversity is dealt with only through the implementation of IBE in rural contexts. In general, what interests me is the connection that is established between the students as Quechua speakers, the Quechua language and a specific territory, and the ideological process of erasing (IRVINE \& GAL, 2000) Quechua speakers from urban areas and cities. Although in Lima half a million of the population declared speaking Quechua at home (National Census, 2007), this is clearly made invisible in the document and national policies in general.

Quechua experts, many of whom currently work in the Ministry of Education, have contributed to the development of the curriculum and are now teaching the Quechua courses in these universities. In alignment with the Ministry of Education, these institutions understand IBE as "the planned educational process that takes place in two languages (Quechua and Spanish) and in two cultures" with the goal

2. Preservice teacher education in IBE has been implemented since the 1980s (see ZAVALA, 2007 for a review), but this is the first time that it has been implemented in a university in Lima and under a government scholarship such as the one mentioned above. 
of "students maintaining and developing not only their language but also other manifestations of their culture" (Program's official curriculum from the university under study). The program implements a sequence of Spanish language courses and another sequence of Quechua language courses within a variety of discipline courses (like history, philosophy or literature) that are taught entirely in Spanish.

None of the students has attended an IBE program during their previous schooling, since the offer of these types of existing programs only benefit $15 \%$ of the population. All of the students come from the Quechua-speaking Southern Andes. Some of them were born and raised in peasant communities, others in small and more urbanized districts, and some in the capital city of one of the Southern regions (such as Cusco or Ayacucho). Nonetheless, many of them also moved along this rural-urban continuum during their short lives. All of them had to qualify as "extremely poor" in order to get the financial support from the government and almost all of them represent the first generation of their families to access higher education.

In what follows, I will discuss four types of dichotomies that the institution under study reproduces in its preservice teacher education program: 1) L1 vs L2, 2) contexts for Spanish use vs contexts for Quechua use, 3) Spanish texts and literacy practices vs Quechua texts and literacy practices, and 4) The Quechua language system vs the Spanish language system. For each dichotomy, I will also discuss the students' reactions.

\subsection{L1/L2}

The institution that implements the teacher-training program in IBE assumes that the students have Quechua as their mother tongue and Spanish as their L2, as used to be the case with the target population of IBE in the 1970s. This representation of the students does not coincide with the complexity of the communicative practices that the students display when they are admitted into the program and the unique and diverse trajectories of bilingualism that they have experienced throughout their lives (for more about this see ZAVALA \& BRAÑEZ, 2017). This is not very different from the situation of more urbanized Quechuaspeaking young activists who live in the main Peruvian cities and who, through new media and other means, want to speak, write, and publish in the indigenous language from more hybrid and fluid practices in relation to language use and identity performance (ZAVALA, forthcoming $b$ ).

Even though the majority of the students have learned Quechua as their "first language," other students are heritage Quechua language speakers or 
emergent bilinguals (GARCÍA, 2009), since they have been exposed to Quechua less than an "L1 speaker" but more than an "L2 speaker" ${ }^{13}$. Emergent bilinguals cannot be categorized in the same way as mother tongue speakers or learners of a second language because they have unique characteristics. They are located in a bilingual continuum that deconstructs artificial categorizations such as "second language learner" versus "fluent speaker," which is difficult to determine (GARCÍA, 2009). Many of the students from the program learned Spanish first and became familiarized with Quechua in a more passive way in different situations of their lives.

Besides these students (who represent 30\% of the student population from the program), the rest of the students who did learn Quechua in their early socialization and who used to speak it regularly before going to primary school feel that this language is not the one they currently speak better. One student, for example, told me that he stopped speaking Quechua when he was six "because my parents forbid me to speak it because I had problems at school." Then he adds: "I identify more with Spanish than with Quechua." Another student also declared:

When I was three I used to speak full Quechua, and my aunts and uncles were mad at me because I used to speak it and told my parents that I should not speak Quechua, that it looks bad, that it sounds horrible, "Don't teach her Quechua". Hence, bit by bit, when I got into kindergarten, I was learning Spanish and I started to adapt myself to Spanish in primary school. I currently understand Quechua perfectly, but I don't speak it.

This shows that language learning does not constitute a merely technical process with a predictable linearity, but that it is linked to issues of identification, prohibition, and above all, power relations (DUFF, 2011). This can be clearly appreciated in the case of Quechua, since the stigmatization towards the language makes the speaker stop using it in different periods of his life. Although the students got into the program because they supposedly speak the indigenous language "as their mother tongue", once they are in it, they face their linguistic condition. As speakers of an oppressed language, they do not know how to write it, they are ashamed of speaking it, and when they try to do so, they feel that they always get stuck. As a Quechua teacher once told me: "Quechua is not like Spanish. It's a

3. 'Heritage language speaker' constitutes a broad category that refers to someone who has some ability in the language that his/her parents or grandparents speak. However, it could also refer to a person whose distant ancestors spoke a language that he/she no longer does. The category has been criticized because it connotes and old language of the past and insists on only one language and not on the bilingual possibilities of the speaker (GARCÍA, 2009). Most recently, some scholars have preferred the term 'emergent bilingual', since "it recognizes the fluidity of bilingual language use, the possibilities of bilingual acquisition and the potentiality of accessing a full range of expressive and communicative possibilities now and in the future" (GARCÍA, 2005). 
paralytic, a tuberculosis sufferer. It's not a language like Spanish, which is healthy. It has gotten sick due to discrimination and has not recovered yet".

But the institution does not only represent these students as speakers of Quechua as their first language but also as learners of Spanish as L2, as if Spanish were a foreign language that does not belong to them, despite the fact that the majority of them have gone through their entire schooling in Spanish and this is the language that they used mostly before they enrolled in the program. For instance, during a Spanish classroom session a teacher told the students: "you have to do it in your language. Now you are doing it in another language, this language that you are learning (Spanish)." This produces a clear-cut differentiation between an "Us" (Spanish speakers) and a "Them" (non-Spanish speakers) within a racializing rhetoric concealed as "culture." Furthermore, teachers argue that students should not study English yet because "they are still making progress with Spanish as L2" (Program Coordinator), despite the fact that the latter are enthusiastic about learning English with the support of the government scholarship.

The students do not understand why the program imparts courses of "Castellano" (Spanish), where teachers assume that they do not know this language and that they are in the process of aquiring it. The students constantly compare these courses of "Castellano" with those of "Lengua" (Language) that are taught in other majors of the same university: "Why is there a difference between "Castellano" and "Lengua?" Why "Castellano" for us and another thing for other students who have the same capacities as we do?" One specific student declared:

They assumed that we knew Quechua. I felt as if they put us away in a corner because we are indigenous, and they must teach us Spanish. If I already know Spanish, how come they want to teach me Spanish? They have made us feel that we don't know how to speak Spanish and that is not true.

The student who told me thatshe stopped using Quechua when he was six years old and ever since had identified more with Spanish than with Quechua pointed out out that: "When I got here, I was shocked to realize that they wanted to teach me Spanish." Another student reported a teacher telling her:

'I can see that you do not master Spanish, this is why you do not understand,' as if speaking Spanish could solve all the difficulties that we have. There are certainly other factors that intervene, like education for instance.

These language ideologies have consequences in the teaching of academic literacy in Spanish, since teachers keep teaching narrative genres or focusing on the sentence or paragraph level within a skills approach, assuming that these students 
will not be able to cope with more challenging content, which could be found in courses of "Lengua" taught to the "regular" students.

In sum, many students feel frustrated because they do not fit in the bilingual ideal that IBE official discourse imposes and that is equivalent to having Quechua as L1 and Spanish as L2 or being "coordinated" bilinguals. Many feel delegitimized because they are represented as Spanish learners and the institution questions their competence in this language. They even declared that some of the "regular" students from other majors have told them that they do not know enough Spanish because they take courses of "Castellano" instead of "Lengua" and that this has made them feel really bad.

This representation of the students as speakers of Quechua as L1 and Spanish as L2 could be framed within the raciolinguistic ideologies that have been discussed lately for other contexts (FLORES \& ROSA, 2015; ALIM et al., 2016). This theoretical framework switches the focus of attention to the listening subject (BLOMMAERT et al., 2005; INOUE, 2003), that is, from the speakers and their language practices towards the listeners and the perceptions that they have about them. In addition, it maintains that the listeners never perceive the speakers' language practices in an objective way but always through the lens of their racialized positioning in the social structure. Therefore, raciolinguistic ideologies fuse certain racialized bodies with linguistic deficiency, in spite of the existence of objective language practices. In the case that I am analyzing, the institution of higher education perceives the students' bilingual repertoires from an ideology of languagelessness (ROSA, 2016), which assumes the limited linguistic capacity of a social group, one that does not necessarily coincide with the students' language abilities and practices. After all, we never have access to reality in a neutral and direct way, but always within the mediation of ideologies, values, and many types of regulations (HALL, 2010).

\subsection{Contexts for Spanish use/contexts for Quechua use}

As I have stated above, contemporary scholarship in bilingualism is currently questioning a notion of bilingualism from a monolingual perspective that does not acknowledge the dynamic and fluid practices that bilinguals engage with in order to produce meaning and communicate in diverse contexts of their lives (CANAGARAJAH，2013; GARCÍA，2009; HELLER, 2007). Nevertheless, teachers from the program under study promote a curricular separation between languages, as if bilingualism implicates a compartmentalization of them, both at the cognitive level and at the level of language use. The courses are taught monolingually 
in the focal language, that is, Spanish in the Spanish courses and Quechua in the Quechua courses. When students use Quechua in Spanish courses the teachers feel uncomfortable and call the students' attention; when they use Spanish in the Quechua courses, the teachers sanction it by saying that a "virus" has got into the classroom, as if the use of Spanish constitutes a betrayal of the indigenous language.

Nevertheless, the students' language resources are clearly not compartimentalized and the simultaneous use of the resources associated with the different named languages constitutes the unmarked practice in many contexts. These include social networks, through which they interact with other Quechuaspeaking youth from other contexts not necessarily related to the university. In what follows I present an example of an interaction on WhatsApp, where the Quechua teacher also participates. Although the use of technology in the Quechua courses is not very common, some teachers activate a WhatsApp or FaceBook group with their students in order to interact in Quechua (but only Quechua!):

Teacher: $\quad$ Yachapakuqkunaaa!!! (students!!!!)

Imaynallam!!! (how are you?)

Kawsakunkichikraqchu? (are you still alive?)

Imallatapas willarikamuychikyaaaa (say whatever you want)

CR7: $\quad$ Allillanmi yachachiq, (we are OK teacher)

Qampas allillancha!!! (are you OK too?)

Pukyu: I am excited

CR7: hahaha

BRJC10: $\quad$ How are you teacher

Tania: Hi!!!.. ¿ ¿How are you teacher??

Teacher: $\quad$ Se han vuelto tribilingues o

trilingües? (have you turned into "tribilingues" ${ }^{4 "}$ or trilinguals?)

\#MR**: $\quad$ Yes

BRJC10: $\quad$ Ari yachachiq (yes teacher)

Teacher: I'm fine

4. "Tribilingüe" comes from "Tribilín", the name, in Spanish, of the Disney character "Goofy", which could connote silliness. 
Tania: $\quad$ Yes, teacher there we go

Ejeejje $^{5}$

Good, i'm fine too

Teacher: $\quad$ kimsa simipi rimayqa (in three languages)

Qapaqyachiwanchikmi (make us powerful)

Javier: Yachaykachimuwaychi plese ${ }^{6}$ (teach me please)

In this example, we can see that these students do not set boundaries among the languages involved (mainly Quechua and English in this case) and that they construct their multilingual identity with no problems. They also use some resources associated with English in a creative way in order to align themselves vis à vis the teacher, although they are not supposed to be learning English yet. However, the teacher does assume a sanctioning posture: "Have you turned into 'tribilingues' or trilinguals?" Although we could analyze this excerpt in more detail, I am mostly interested in showing that the teacher ends up "throwing in the towel", using English himself and acknowledging that the use of the three named languages could be positive and empowering.

\subsection{Spanish texts and literacy practices/Quechua texts and literacy practices}

The program also constructs a division between what is read and written in Spanish and what is read and written in Quechua within a dualistic approach to literacy (CANAGARAJAH, 2013) or a particular "Great Divide," which claims fundamental differences between "kinds" of languages and of literacies (and of peoples and cultures as well) and assumes that minoritized languages have their own norms and values that must be preserved. While in Spanish the students learn to write academic texts, the situation in Quechua is very different. In the six Quechua courses of the university program, teachers promote the production - and mainly the record or compilation - of "literary" texts such as stories, traditional chants, poems, and riddles. At first, I thought that the teaching of Quechua writing could be framed within the discourse of creativity (although with particular specifications), following Ivanic's categorization of six discourses of writing (skills, creativity, process, genre, social practices, and sociopolitical). Ivanic (2005) points out that

5. This represents a laugh.

6. Javier writes "plese" for the English word "please". 
the discourse of creativity has influences from literature and is concerned with content and style rather than linguistic form. This approach has been privileged in contexts of minorities and vulnerable populations, since it has been used to give voice through vernacular practices. However, it has also been considered romantic and asocial and as authorizing disadvantage by encouraging learners to write texts that will not be valued in the real world (IVANIC, 2005).

Now, despite the fact that the record or compilation of literary texts is conducted without much guidance or regulation, there is also an emphasis on the standardization of writing and the use of "pure and authentic Quechua," in the sense of the production of texts within the standardized alphabet and no use of Spanish loanwords. For instance, students are asked to interview peasants, transcribe what they have taperecorded and finally, standardize the written product. They are also asked to listen to -and tape record - cultural rituals and then transcribe them with a standardized Quechua. Hence, students must write about the traditions that they supposedly know within defined norms of grammatical and orthographic correctness that they must obey. As one of the students declared, "What we do is to correct what the grandfather tells us". This discourse of "writing the cultural knowledge of our people" does not seem to fit in earlier typifications of discourses of writing and learning to write, in the sense of configurations of beliefs and practices in relation to the teaching of writing, such as the one proposed by Ivanic (2005). It could, instead, be situated within a discourse that I am calling "writing as a cultural archive." Conceptualizing literacy as a social practice -and not a technical skillallows us to reveal how reading and writing is embedded in the construction of identities and the reproduction and contestation of language ideologies and wider ideologies in general (STREET, 2001). Literacy, as inherently ideological, always constitutes an active process of meaning making and contest over definition.

Within this orientation of "writing as a cultural archive", the program does not promote Quechua writing for communicative purposes or with a specific audience in mind but only to remember and learn about cultural traditions. Besides this absence of a communicative function, Quechua teachers ask students to write about particular topics that are assumed as intrinsically linked to the language. Hence, they favor the writing about "elements of their culture": "things from their community, their parents, their cosmovision" (Quechua teacher), as if the students' culture constitutes only what is related to the peasant world from the rural context. The imperative is clearly not to forget the ancestral values, with the goal of maintaining the sense of belonging to their places of origin. It is not surprising, 
then, that the Quechua courses do not incorporate digital or new media platforms for developing reading and writing activities online.

Even though when the students start the program they mostly accept how and what they are taught from Quechua experts, as they advance in their studies, they start to question the approach used in the Quechua courses. They are critical of the fact that the teachers only promote the production of literary texts or that they spend too much time discussing textbook materials elaborated by the Ministry of Education for primary IBE schools. "We wanted more," pointed out one of the students in a focus group. Another one added: "I have always wanted to write, for instance, a paper or a monograph in Quechua. We would also like to write our thesis in Quechua". Many students ask for other types of texts in Quechua and are starting to write in Quechua within different types of practices. One of them points it out in a very direct way: "Writing only poems and stories is limiting, and you are tempted to think that your language is only useful for literary aspects, and not for academic ones or for research." As a matter of fact, there are many students who would like to engage with Quechua writing but not only for "remembering" ancestral experiences or vivencias. In fact, currently some of them are developing alternative practices through social networks, virtual journals, and other spaces of which the teaching training program does not take advantage.

In contrast to the discourse of IBE, which targets a specific kind of Quechua speaker (rural, "L1", ancestral values, etc.), the students from the program feel part of a broader community that includes those who have not learned Quechua as their mother tongue and even those who are interested in learning it from scratch. In terms of literacy, they also want to incorporate the latter: "We should write for Quechua-speaking people but also for those who are non-Quechua-speaking, but in Quechua. It's not that you want to impose your Quechua, nor teach them Quechua forcibly, but invigorate the language", declared a student from the program. With that aim, one of the students, for example, declared that he wants to write in Quechua for Spanish-speaking people but using strategies that could help them understand the language. He mentions the inclusion of glossaries in the case of texts or subtitles in Spanish in the case of videos. His point is the following: "Today's struggle should be the everyday nature of Quechua, not vindication or claims, not even inclusion, but the everyday nature itself. Only by turning Quechua into an everyday language we will guarantee its survival in public spaces, in academic ones, in everything."

In addition, the students want to write, not only to remember an ancestral practice, but to be read and listened to. One of them declared: "the symbolic is 
OK, I publish a book of poems, that's nice, that sells, it is fashionable. But what I really want is to be read, to be cited, I would like to cite other people [who write in Quechua] too." Another one asked: "Do you want your writing to be used in different domains or will you write for theorists and intellectuals, or for the teacher to grade you and that's it?" The students realize that earning a voice does not only imply the power to say things in their language (as when they write about their places of origins and their ancestral practices) but, above all, to be heard by other people and also to be able to influence them (RUIZ, 1997).

Motivated by the above, a group of students decided to create their own virtual library in Quechua (and in Spanish), which they are using to "disseminate what we could do with the language." This Web page does not only include a virtual library but also a journal where the students write in both languages "about reflective topics that are affecting us" (according to one of them). In this platform, we can find poems and literary criticisms of those poems, a letter addressed to the Peruvian president, a reflection about multilingualism not being a problem, a critique about the notion of interculturality, etc. A student who wrote a literary commentary in Quechua about another student's book of poems received a message from a Peruvian writer who lives in Paris, who proposed that she should develop a more ambitious literary work that would incorporate four books of poems. "Since that happened, several people are starting to know me," she declared. Clearly, writing in Quechua is inserting both the language itself and Quechua writers into another paradigm: "It is a way of writing more academically, and it's writing in Quechua not for a reduced audience but for a more general one that includes Spanish-speaking people, Quecbua-speaking people, bilinguals and everybody" (student from the program, emphasis added). Many other young Quechua activists from other contexts are writing in Quechua within this same logic. One videoblogger from Abancay declared that her work will benefit all Peruvians: "those who know how to speak the language but also those who do not know, but who will start speaking it."

\subsection{The Quechua linguistic system/the Spanish linguistic system}

As have been discussed above, teachers also talk about Quechua in ideal terms, as if the students (and even peasants from rural communities) were monolinguals with a "pure" and "non-contaminated" Quechua from Spanish influence and not bilinguals who are constantly developing translingual practices. This is observed when students are policed whenever they incoporate Spanish in their Quechua communicative practices, either in oral speech or written texts. For instance, in one of the Quechua courses, the students were asked to spend almost half of the 
semester "correcting" a peasant testimony that was published three decades ago. This meant that they needed to standardize the alphabet and replace Spanish loanwords with Quechua "authentic" terms. The goal was to recover a Quechua language that does not exist anymore and that is very distant from Spanish and bilingual contemporary practices.

Besides challenging the classical writings that are being developed in the indigenous language, the students also consider that the "pure" Quechua that is used in the classroom does not reflect the current bilingual identity that they intend to display. For instance, one of the students commented that he feels constrained during the Quechua courses because he is being trained as a monolingual Quechua isolated from contemporary language practices. Moreover, he pointed out that when he visits his parents and speaks "in his intellectual and academic Quechua," this has not worked for him because people do not understand him. Another student also declared that when she tries to use the type of Quechua that is favored in the classroom: "I have difficulties to converse with my mom." For these students, this type of Quechua does not fit in a world of Quechua bilinguals and trilinguals; a world where "not even my grandfather speaks pure Quechua", as one of them stated. This idea is aligned with what a Quechua activist from Cusco once told me: "I see much solemnity in academic Quechua. You can't use that Quechua for everyday expressions." One student from the program states it bluntly:

Either you opt for bilingualism or you turn into someone so Quechua or mono Quechua; thus, this is what you have to figure out and this is not being discussed (in the courses). This is an issue that we should discuss in relation to Quechua literacy. What do we want today? Do we adapt to today's context or do we really want, as my uncle says, right? 'Enough! Spanish got here by God's grace, so now we will give it back to Spain in a package and we will stay only with the Quechua language.' Either we do that or we adapt ourselves to such a bilingual context of today's world.

In sum, the Quechua teachers from this program reproduce specific practices in Quechua influenced by different language ideologies: (i) They conceive language more as structure and competence than as practice, (ii) defend a discourse of language preservation oriented toward the past (DUCHENE \& HELLER, 2008), (iii) sustain a rigid and fixed connection between language, community and place (CANAGARAJAH, 2013), (iv) talk about Quechua as if students were monolinguals and not bilinguals who constantly develop translingual practices and (v) promote the separation of languages and other types of dichotomies (such as L1/L2, local/ global, authentic/non-authentic) that have been part of the discourse of IBE in Perú and other contexts. 
In contrast to Quechua experts, young people are starting to inscribe the use of Quechua within new social practices. Instead of excluding others through literacy knowledge, linguistic terminology, or other means (ZAVALA, forthcoming a), they are trying to construct a wide community that includes not only "native" speakers but also heritage, emergent, and new speakers (O'ROURKE et al., 2015). Moreover, since they want to reach a wider audience, they are not so driven by orthography, language purity, and essentializing connections of language and culture. They are more interested in using New Media and multimodal literacy because they want to be read and listened to as they display themselves as contemporary bilinguals.

\section{FINAL THOUGHTS}

The analysis of this program has shown that its Intercultural Bilingual Education model promotes dichotomies where languages are conceptualized as things and not as practices. All of these dichotomies conceal the same epistemological frame: a positivist and autonomous view of language that favors the focus on the language system and not on language use, on truth and not on ideology, on stability and not on change.

For the students enrolled in this program, Quechua and Spanish are not equivalent to mutually exclusive ways of being; rather, they relate in dynamic ways to the subjectivities that they display in different contexts. For many of them, their trajectories of bilingualism and the communicative repertoires that they have developed do not fit in the official discourse of IBE, in which the "true" Quechua speaking people would be only those with a traditional past and a mother tongue not contaminated by Spanish. The consequence of this dominant representation is that many bilinguals feel forced to assimilate to an ideal monolingual norm. Furthermore, many of them even feel deligitimized and excluded from the program and the IBE project in general. This deligitimation of speakers on the basis of the idea that they are not using the "correct" form of language in relation to the identity that they are claiming has been observed in many other contexts (PAVLENKO \& BLACKLEDGE, 2004; BAILEY, 2000; SHENK, 2007; BUCHOLTZ \& HALL, 2004).

Many researchers have argued that an exclusive focus on academic registers can affect the speakers' attitudes towards their vernacular language use and the sociocultural heritage that they index. In that sense, in many biliterate programs, teachers promote texts from minoritized authors, written in vernacular genres and styles and within a more contextualized language (HORNBERGER \& SKILTON- 
SYLVESTER, 2000). However, the dichotomies between Spanish and Quechua that I have discussed can reproduce "a discourse of preservation" (HILL, 2002), which runs the risk of (i) fixing the texts, the genres and the literacy practices, as if these did not change, (ii) invisibilizing cultural contact, (iii) promoting an exoticizing and romantizicing perspective that anchors indigenous languages (and people who speak them) in the past, and (iv) of constructing a boundary between Quechua and Spanish that does not reflect what people do with the language resources in their daily lives.

Based on these two groups of social actors in a specific educational program, my study reveals a tension that has been developing in the last decade between traditional and post-traditional approaches to language policy and revitalization (PIETIKÄINEN et al., 2016): while the older generation of "Quechua experts" are trying to guarantee the linguistic human rights of first-language Quechua speakers who mostly live or have lived in rural areas, their younger Quechua counterparts are opting for a more innovative and creative route. They are trying to reverse the status of Quechua through the use of the language in urban everyday life and by getting more people knowing, learning, and using it.

Nonetheless, I believe that the above-mentioned distinction should not be dichotomous either. I am aware of the dangers that a postmodern concept of speakers and languages can bring for the protection of minority languages (PIETIKÄINEN \& KELLY-HOLMES, 2011) and of the fact that a concept of language with clear boundaries may "protect" minoritized languages in granting for funding sources and qualifying for rights from national and international bodies. But Peruvian history has demostrated that this option has not necessarily guaranteed the growth of the languages; on the contrary, it has excluded and disempowered a great number of speakers from the language policy process and has created social difference, hierarchies, and inequalities within Quechua speakers themselves.

Many revitalization agendas attempt to "revive" a language within its "original" forms and practices (JAFFE, 2015). However, this is imposible. We cannot think about the future of Quechua if we do not take into account that communities of practice have been transformed, that they are now populated by people with different types of knowledge, that they are acquiring the language through different means in relation to the past, and that now there are different ideological regimes implicated. Furthermore, when the dichotomies discussed in this article are promoted, everything remains in its place and inequality is reproduced. After all, the aim of bilingual education is not to maintain everything in its place. Its aim is to develop language learning but also to reconstruct the value 
of the different languages involved and discuss who has the right to use them and in which circumstances (HELLER, 2011).

Therefore, the struggle should no longer be to preserve a pure well-bounded and essential collection of structural and lexical features associated with Quechua, but to advocate for the cultural-linguistic complex set of practices that people currently use (OTHEGUY et al., 2015). Although Quechua needs protection in order to grow, especially because it is always under the threat of being oppressed by Spanish, the conceptualization of Quechua as a bounded, objectified homogeneous and structural system has produced limiting and fictitious views on how it is operating in the world, as this study has revealed. In contrast to experts, who are privileging a "scientific" discourse on language over everyday understandings of it, these students' local knowledge and practices are desinventing languages (MAKONI \& PENNYCOOK, 2006). I am tempted to believe that only through the disinvention of Quechua and the valuing of more semiotic practices will there be more and new speakers of the language (OTHEGUY et al., 2015).

The students under study position themselves as speakers of Quechua in urban, global, mobile, and transnational contexts. They are speakers of Quechua but also of Spanish; they are traditional but also contemporary; they are rural but also urban; they are local but also global; they are indigenous but at the same time, they are not. And they do not like it when they are told in the institution of higher education that their only choice when they graduate will be to work as bilingual teachers or as "chakra maestros" in rural peasant communities.

\section{REFERENCES}

ALIM, H. S., RICKFORD, J.; BALL., A. (eds.) (2016). Raciolinguistics: How language shapes our ideas about race. New York: Oxford University Press.

BAILEY, B. (2000). Language and negotiation of racial/ethnic identity among Dominican Americans. Language in Society, 29, 555-582.

BLACKLEDGE, A.; CREESE, A. (2010). Multilingualism: A critical perspective. London: Continuum.

BLOMMAERT, J. (2010). The sociolinguistics of globalization. Cambridge: Cambridge University Press. 
BLOMMAERT, J.; BACKUS, E. (2011). Repertoires revisited: "Knowing language" in superdiversity. Working Papers in Urban Language and Literacies, 67.

BLOMMAERT, J.; COLLINS, J.; SLEMBROUCK, S. (2005). Spaces of multilingualism. Language \& Communication 25, 197-216.

BUCHOLTZ, M. (2002). Youth and cultural practice. Annual Review of Antbropology, 31 : 525-552.

BUCHOLTZ, M. \& HALL, K. (2004). Language and identity. In: Duranti, A. (ed.), A companion to linguistic antbropology, Vol. 1. Oxford: Blackwell, pp. 369-394.

CANAGARAJAH, S. (2013). Translingual practice. Global englishes and cosmopolitan relations. New York: Routledge.

CUMMINS, J. (2008). Teaching for transfer: challenging the two solitudes assumption in bilingual education. In: Cummins, J. and Hornberger, N. (eds.), Encyclopedia of Language and Education (vol. 5: Bilingual Education). Boston: Springer, pp. 65-75.

DUCHENE, A.; HELLER, M. (2008). Discourses of Endangerment: Ideology and Interest in the Defense of Languages. New York: Continuum.

DUFF, P. (2011). Second language socialization. In: Duranti, A.; Ochs, E.; Shieffelin, E. (eds.), Handbook of language socialization. Oxford: Blackwell, pp. 564-586.

FLORES, N. \& ROSA, J. (2015). Undoing appropriateness: Raciolinguistic ideologies and language diversity in education. Harvard Educational Review, 85(2): 149-171.

GAL, S. (2018). Visions and Revisions of Minority Languages. Standardization and its dilemmas. In: Lane, P.; Costa, J.; de Korne, H. (eds.), Standardizing Minority Languages. Competing Ideologies of Authority and Authenticity in the Global Periphery. New York: Routledge, pp. 222-242.

GARCÍA, M. E. (2005). Making indigenous citizens. Identity development, and multicultural activism in Perú. California: Stanford University Press.

GARCÍA, O. (2005). Positioning heritage languages in the United States. Modern Language Journal, 89 (4): 601-605.

GARCÍA, O. (2009). Bilingual education in the 21st century. A global perspective. New York: WileyBlackwell. 
GARCÍA, O.; FLORES, N.; SPOTTI, M. (2017). Introduction. Language and society. A critical poststructuralist perspective. In: García, O.; Flores, N.; Spotti, M. (eds.), The Oxford Handbook of Language and Society. Oxford: Oxford University Press, pp. 1-16.

HALL, S. (2010). El trabajo de la representación. In: Restrepo, E.; Walsh, C.; Vich, V. (eds.), Sin garantías. Lima: Instituto de Estudios Peruanos, pp. 445-480.

HELLER, M. (2007). Bilingualism as ideology and practice. In: Heller, M. (ed.), Bilingualism: A social approach. New York: Palgrave, pp. 1-22.

HELLER, M. (2011). Patbs to post-nationalism: A critical etbnograpby of language and identity. Oxford: Oxford University Press.

HILL, J. H. (2002). 'Expert Rhetorics' in Advocacy for Endangered Languages: Who is Listening, and What Do They Hear? Journal of Linguistic Antbropology, 12 (2), 119-133.

HORNBERGER, N. (1995). Five vowels or three? Linguistics and politics in Quechua language planning in Perú. In: Tollefson, J. (ed.), Power and inequality in language education. Cambridge: Cambridge University Press, pp.187-205.

HORNBERGER, N. (2000). Bilingual education policy and practice in the andes: Ideological paradox and intercultural possibility. Antbropology and Education Quarterly, 31(2), 173-201.

HORNBERGER, N.; SKILTON-SYLVESTER, E. (2000). Revisiting the continua of biliteracy: International and critical perspectives. Language and Education, 14 (2), 96 122.

HORNBERGER, N.; SWINEHART, K. (2012). Bilingual intercultural education and Andean Hip Hop: Transnational sites for indigenous language and identity. Language in Society 41: 499-525.

INOUE, M. (2003). Speech without a Speaking Body: "Japanese Women's Language" in Translation. Language and Communication, 23: 315-330.

IRVINE, J. T.; GAL, S. (2000). Language ideology and linguistic differentiation. In: Kroskrity, P. (ed.), Regimes of language. Ideologies, polities and identities. New Mexico: School of American Research Press, pp. 35-84.

IVANIC, R. (2005). Discourses of writing and learning to write. Language and Education, 18 (3), 220-245. 
JACQUEMET, M. (2005). Transidiomatic practices: language and power in the age of globalization. Language \& Communication, 25: 257-277.

JAFFE, A. (2007). Discourses of endangerment: Contexts and consequences of essentializing discourses. In: Duchene, A.; Heller, M. (eds.), Discourses of endangerment. London: Continuum, pp. 57-75.

JAFFE, A. (2015). Defining the New Speaker. Theoretical Perspectives and Learner Trajectories. International Journal of the Sociology of Language, 231: 21-44.

JOHNSON, D. C. (2013). Language policy. Basingstoke: Palgrave Macmillan.

JØRGENSEN, J.; KARREBAEK, M.S.; MADSEN, L.M.; MØLLER, J. S. (2011). Polylanguaging in Superdiversity. Diversities, 13(2): 23-37.

McCARTY, T. L.; ROMERO-LITTLE, M. E.; WARHOL, L. (2009). Indigenous youth as language policy makers. Journal of Language, Identity and Education, 8: 291-306.

MAKONI, S.; PENNYCOOK, A. (eds.). (2006). Disinventing and reconstituting languages. Clevedon: Multilingual Matters.

MARTIN-JONES, M.; MARTIN, D. (eds.). (2017). Researching Multilingualism. Critical and Ethnographic Perspectives. London: Routledge.

O'ROURKE, B., PUJOLAR, J. \& RAMALLO, F. (2015). New speakers of minority languages: The challenging opportunity. International Journal of the Sociology of Language: 231

OTHEGUY, R.; GARCÍA, O.; REID, W. (2015). Clarifying Translanguaging and Decontructing Named Languages. A Perspective from Linguistics. Applied Linguistics Review, 6 (3): 281-307.

PAVLENKO, A.; BLACKLEDGE, A. (2004). Negotiation of identities in multilingual contexts. Clevedon: Multilingual Matters.

PENNYCOOK, A. (2001). Critical applied linguistics: A critical introduction. New Jersey: Lawrence Erlbaum.

PENNYCOOK, A. (2010). Language as a Local Practice. New York: Routledge. 
PIETIKÄINEN, S.; KELLY-HOLMES, H. (2011). Gifting, Service, and Performance: Three eras in Minority-language Media Policy and Practice. International Journal of Applied Linguistics, 21 (1): 51-70.

PIETIKÄINEN， S.; KELLY-HOLMES， H.; JAFFE， A.; COUPLAND， N. (2016). Sociolinguistics from the periphery. Small languages in new circumstances. Cambridge: Cambridge University Press.

Programa Nacional de Becas y Crédito Educativo. (2014). Beca 18. Educación Intercultural Bilingiie. Expediente Técnico. Lima: Ministerio de Educación.

ROSA, J. (2016). Standardization, racialization, languagelessness: Raciolinguistic ideologies across communicative contexts. Journal of Linguistic Antbropology, 26(2): 162-183.

RUIZ, R. (1997). The Empowerment of Language-Minority Students. In: Darder, A.; Torres, R. D. \& H. Gutiérrez (eds.), Latinos and Education: A Critical Reader. New York: Routledge, pp. 319-328.

RYMES, B. (2014). Communicating beyond language. Everyday encounters with diversity. London: Routledge.

SCOLLON, R.; SCOLLON, S. W. (2004). Nexus Analysis. Discourse and the Emerging Internet. New York: Routledge.

SHENK, P. S. (2007). "I'm Mexican, remember?" Constructing ethnic identities via authenticating discourse. Journal of Sociolinguistics, 11, 194-220.

STREET, B. (2001). The New Literacy Studies. In: Cushman, E.; Kintgen, E.R.; Kroll, B.M.; Rose, M. (eds.), Literacy: A Critical Sourcebook. Boston: St. Martin's, pp. 430-442.

TRAPNELL, L.; ZAVALA, V. (2013). Dilemas educativos ante la diversidad. Volumen XIV de la Colección del la Historia del Pensamiento Educativo Peruano. Lima: Derrama Magisterial.

VALDÉS, G. (2017). Entry visa denied: The construction of symbolic language borders in educational settings. In: García, O.; Flores, N. \& Spotti, M. (eds.), The Oxford Handbook of Language and Society. Oxford: Oxford University Press, pp. 321-348.

VALDIVIEZO, L. (2009). Bilingual Intercultural Education in Indigenous schools: An ethnography of teacher interpretations of government policy. International Journal of Bilingual Education and Bilingualism, 12(1): 61-79. 
WYMAN, L. T., McCARTY, T. L.; NICHOLAS, S. E. (2014). Indigenous Youth and Multilingualism. Language Identity, Ideology, and Practice in Dynamic Cultural Worlds. New York: Routledge.

ZAVALA, V. (2007). Una mirada a la formación docente en educación intercultural bilingüe en la zona andina del Perú. In: Cuenca, R.; Nucinkis, N.; Zavala, V. (eds.), Nuevos maestros para América Latina. Madrid: Morata. 162-189.

ZAVALA, V. (2014a). What is Quechua literacy for?: Ideological dilemmas in intercultural bilingual education in the Peruvian Andes. In: Prinsloo, M.; Stroud, C. (eds.), Educating for Language and Literacy Diversity: Mobile Selves. Nueva York: Palgrave Macmillan.

ZAVALA, V. (2014b). An ancestral language to speak with the "Other": Closing down ideological spaces of a language policy in the Peruvian Andes. Language Policy, 13 (1): $1-20$.

ZAVALA, V.; BRAÑEZ, R. (2017). Nuevos bilingüismos y viejas categorías en la formación inicial de docentes. Revista Peruana de Investigación Educativa, 9: 61-84.

ZAVALA, V. (Forthcoming a). Tactics of intersubjectivity and boundary construction in language policy: An Andean case. To appear in Language, Identity and Education.

ZAVALA, V. (Forthcoming b). Jóvenes, activismo y repolitización del quechua. In: Oliart, P. (ed.), Pedagogías del disenso: Creación de nuevos sentidos desde el activismo y la producción cultural.

Recebido: 24/08/2018

Aceito: 04/10/2018 